www.nature.com/ja

\title{
New milbemycins from mutant Streptomyces bingchenggensis $\mathrm{X}-4$
}

\author{
Bao-Xin Zhang ${ }^{1}$, Hui Zhang, ${ }^{2,3}$, Xiang-Jing Wang ${ }^{1}$, Ji-Dong Wang ${ }^{2}$, Chong-Xi Liu ${ }^{1}$ and Wen-Sheng Xiang ${ }^{1}$
}

The Journal of Antibiotics (2011) 64, 753-756; doi:10.1038/ja.2011.75; published online 17 August 2011

Keywords: milbemycin $\beta_{15}$; seco-milbemycins $\mathrm{E}$ and $\mathrm{F}$; Streptomyces bingchenggensis

Streptomyces bingchenggensis produced milbemycins, including $\alpha_{1}\left(\mathrm{~A}_{3}\right), \alpha_{3}\left(\mathrm{~A}_{4}\right), \beta_{13}, \beta_{14}, \alpha_{28}, \alpha_{29}, \alpha_{30}$ and ST 906, four secomilbemycins $\mathrm{A}, \mathrm{B}, \mathrm{C}$ and $\mathrm{D}$, and two cyclic pentapeptides. ${ }^{1-5}$ Milbemycins belong to a 16-membered macrolide antibiotic with an outstanding activity against various kinds of mites. ${ }^{6}$ During a screening program for high production of $\mathrm{A}_{3}$ and $\mathrm{A}_{4}$, a mutant S. bingchenggensis X-4 was obtained by UV treated, $N$-methyl- $N^{\prime}$ nitroso- $N$-nitroso-guanidine mutation and genetic manipulative techniques. Significant differences of phenotype, such as the morphology of aerial mycelia, and the metabolite HPLC profiles were observed between the wild-type $S$. bingchenggensis and its mutant strain X-4. In the course of investigating the metabolites of this mutant strain, three new interesting compounds milbemycin $\beta_{15}$ (1), seco-milbemycins E (2) and F (3) were isolated from the fermentation broth of S. bingchenggensis X-4. The structure of compound 1 was similar with milbemycin $\mathrm{D}$, which is a highly selective and potent nematocide and insecticide. ${ }^{7}$ So the bioactivity of compound 1 should be further investigated. Compared with the seco-milbemycins isolated previously, ${ }^{2,3}$ the hydroxy groups at C-5 were absent in compounds 2 and 3. Furthermore, all the milbemycins ${ }^{3,8}$ and avermectins ${ }^{9,10}$ obtained from microorganisms contain the hydroxyl at C-5, and the 5-dehydroxyl derivatives of milbemycins and avermectins can only be obtained using the synthetic methods. ${ }^{11}$ So seco-milbemycins E and $\mathrm{F}$ may have an important role in understanding and perfecting the proposed biosynthesis pathways of milbemycins.

The producing strain $S$. bingchenggensis X-4 was maintained on an $1 / 2 \mathrm{YM}$ slant agar consisting of sucrose $0.4 \%$, skim milk $0.1 \%$, yeast extract (OXOID Basingstoke, Hampshire, UK) 0.2\%, malt extract (BD Biosciences, San Jose, CA, USA) $0.5 \%$, agar (BD Biosciences) $2.0 \%$ at $28^{\circ} \mathrm{C}$ for 12 days. $^{12}$ A seed $15-1$ fermentor (FUS-15L (A), Shanghai Guoqiang Bioengineering Equipment, Shanghai, China) containing 101 of seed medium (sucrose $1.0 \%$, polypepton $0.2 \%, \mathrm{~K}_{2} \mathrm{HPO}_{4} 0.05 \%$, skim milk $0.05 \%)^{12}$ was inoculated with $0.5 \mathrm{l}$ of broth cultured in flask with seed medium. The flask with seed medium $\left(2-6 \times 10^{7}\right.$ spores per ml) was cultured for $30 \mathrm{~h}$ at $28^{\circ} \mathrm{C}$ on a rotary shake at 250 r.p.m.
After incubation for $32 \mathrm{~h}$, the seed broth (31) in the 15-l fermentor was transferred into the production 50-1 fermentor (FUS-50 L (A), Shanghai Guoqiang Bioengineering Equipment) containing 30-1 production medium (16.0\% sucrose, $2.0 \%$ soybean powder, $0.5 \%$ yeast extract, $0.5 \%$ meat extract, $0.05 \% \mathrm{~K}_{2} \mathrm{HPO}_{4}, 0.05 \% \mathrm{MgSO}_{4} 7 \mathrm{H}_{2} \mathrm{O}$, $0.005 \% \mathrm{FeSO}_{4} 7 \mathrm{H}_{2} \mathrm{O}$ and $\left.0.3 \% \mathrm{CaCO}_{3}\right) .{ }^{12}$ The culture temperature was $28^{\circ} \mathrm{C}$ and the initial $\mathrm{pH}$ was 7.40 sterilized by sparging with steam at $121{ }^{\circ} \mathrm{C}$ for $30 \mathrm{~min}$. The dissolved oxygen was maintained above $35 \%$ by adjusting the agitation speed. The initial aeration and agitation rate in the 15-1 reactor was $1 \mathrm{vvm}$ and 180 r.p.m., whereas those in the 501 were $0.8 \mathrm{vvm}$ and 150 r.p.m., respectively. In the process of fermentation, the $\mathrm{pH}$ was not controlled. The fermentation was performed for 10 days at $28^{\circ} \mathrm{C}$.

The fermentation broth (301) was filtered. The resulting cake was washed with water, and both filtrate and wash were discarded. Methanol (10l) was used to extract the washed cake. The $\mathrm{MeOH}$ extract was evaporated under reduced pressure to $\sim 21$ at $45^{\circ} \mathrm{C}$ and the resulting concentrate was extracted three times using an equal volume of EtOAc. The combined EtOAc phase was concentrated under reduced pressure to yield $30 \mathrm{~g}$ of oily substances. The residual oily substance was chromatographed on silica gel (Qingdao Haiyang Chemical Group, Qingdao, China; 100-200 mesh) and eluted with a petroleum ether-acetone mixture (100:0-50:50, v/v). The fractions eluted with the petroleum ether-acetone mixture (90:10, v/v) were combined and evaporated to obtain fraction I and the fractions eluted with the petroleum ether-acetone mixture $(85: 15, \mathrm{v} / \mathrm{v})$ were pooled and concentrated to give fraction II. The fraction I was subjected to Sephadex LH-20 (GE Healthcare, Glies, UK) gel column eluting with $\mathrm{MeOH}$ to give subfraction I. The semi-preparative HPLC (Agilent 1100, Zorbax SB-C18, $5 \mu \mathrm{m}, 250 \times 9.4 \mathrm{~mm}$ i.d.; Agilent, Palo Alto, CA, USA) was applied to obtain pure compounds. The eluates were monitored using a photodiode array detector at $220 \mathrm{~nm}$, and the flow rates were $1.5 \mathrm{ml} \mathrm{min}^{-1}$ at room temperature. The subfraction I was further separated by semi-preparative HPLC using a solvent containing a $\mathrm{CH}_{3} \mathrm{OH}-\mathrm{H}_{2} \mathrm{O}$ mixture $(95: 5, \mathrm{v} / \mathrm{v})$ to obtain compounds

${ }^{1}$ Life Science and Biotechnology Research Center, School of Life Science, Northeast Agricultural University, Harbin, PR China; ${ }^{2}$ Department of New Drug Screening, Zhejiang Hisun Pharmaceutical, Zhejiang, PR China and ${ }^{3}$ Division of Pharmaceutical Science, College of Pharmaceutical Science, Zhejiang University of Technology, Hangzhou, PR China Correspondence: Professor W-S Xiang, Life Science and Biotechnology Research Center, School of Life Science, Northeast Agricultural University, Harbin 150030, PR China. E-mail: xiangwensheng@yahoo.com.cn

Received 6 April 2011; revised 18 July 2011; accepted 21 July 2011; published online 17 August 2011 


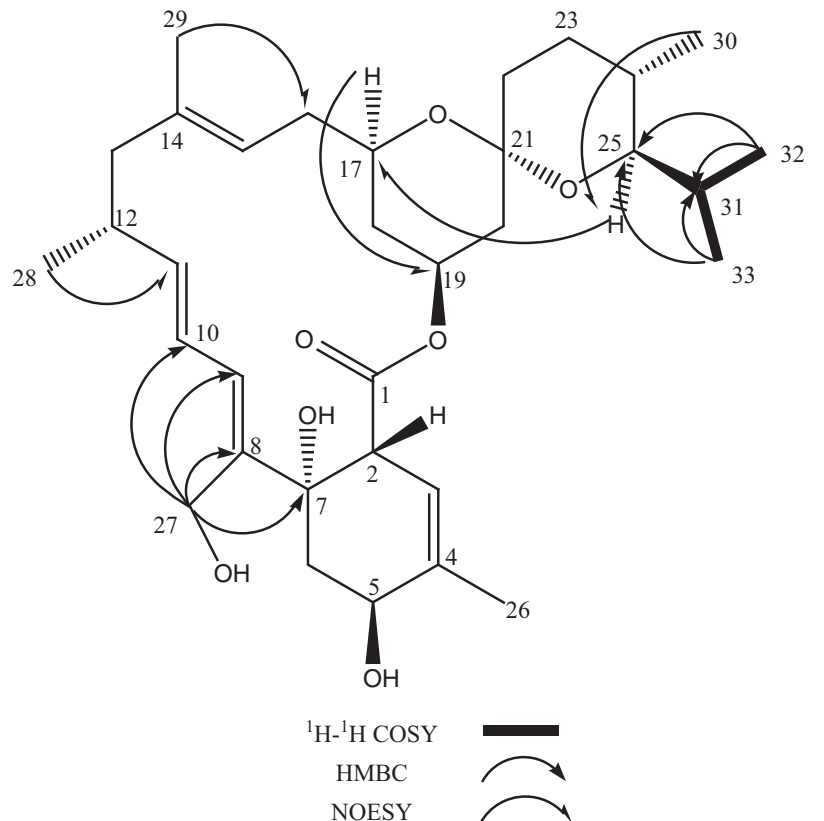

Figure 1 The structure and key correlations of ${ }^{1} \mathrm{H}_{-}{ }^{1} \mathrm{H}$ COSY and $\mathrm{HMBC}$ of compound 1.
$2\left(t_{\mathrm{R}} 14.5 \mathrm{~min}, 14 \mathrm{mg}\right)$ and $3\left(t_{\mathrm{R}} 16.2 \mathrm{~min}, 18 \mathrm{mg}\right)$. The fraction II was subjected to Sephadex LH-20 gel column eluting with $\mathrm{MeOH}$ to give subfraction II. The subfraction II was purified by the semi-preparative HPLC using a solvent containing a $\mathrm{CH}_{3} \mathrm{OH}-\mathrm{CH}_{3} \mathrm{CN}-\mathrm{H}_{2} \mathrm{O}$ mixture $(48: 45: 7, \mathrm{v} / \mathrm{v} / \mathrm{v})$ to obtain compound $1\left(t_{\mathrm{R}} 24.5 \mathrm{~min}, 13 \mathrm{mg}\right)$.

Compound 1 (Figure 1) was isolated as colorless oil with UV $(\mathrm{EtOH}) \lambda_{\max }(\mathrm{nm})(\log \varepsilon): 242(4.21)$ and $[\alpha]_{\mathrm{D}}^{25}+87(\mathrm{c} 0.10$, EtOH). Its molecular formula was established to be $\mathrm{C}_{33} \mathrm{H}_{50} \mathrm{O}_{7}$ as deduced from the high-resolution electrospray ionization (HRESI)-MS $\mathrm{m} / z 581.3451$ $\left((\mathrm{M}+\mathrm{Na})^{+}\right.$, calcd for $\left.\mathrm{C}_{33} \mathrm{H}_{50} \mathrm{O}_{7} \mathrm{Na}, 581.3449\right)$ and ${ }^{13} \mathrm{C}$ NMR data (Table 1). The IR spectrum of 1 showed absorption bands assignable to the hydroxyl group $\left(3450 \mathrm{~cm}^{-1}\right)$ and an ester carbonyl $\left(1715 \mathrm{~cm}^{-1}\right)$. The ${ }^{1} \mathrm{H}$ NMR $\left(400 \mathrm{MHz}, \mathrm{CDCl}_{3}\right)$ data (Table 1) of compound 1 exhibited one trans double bond at $\delta 5.50(\mathrm{dd}, J=14.6,9.9 \mathrm{~Hz})$ and $\delta$ 6.26 (dd, $J=14.6,11.2 \mathrm{~Hz}$ ), two olefinic methyls at $\delta 1.59$ (br s), 1.85 (br s), and four doublet aliphatic methyls at $\delta 0.79(\mathrm{~d}, J=6.1 \mathrm{~Hz}), 0.84$ (d, $J=6.8 \mathrm{~Hz}), 1.01\left(\mathrm{~d}, J=7.0 \mathrm{~Hz}\right.$ ) and $1.03(\mathrm{~d}, J=6.8 \mathrm{~Hz})$. Its ${ }^{13} \mathrm{C} \mathrm{NMR}$ and DEPT data (Table 1) showed 33 carbon resonances, including an ester carbonyl at $\delta 173.5(\mathrm{~s})$, a ketal at $\delta 97.4(\mathrm{~s})$, one oxygenated methylene at $57.8(\mathrm{t})$, four oxygenated methines at $\delta 78.3(\mathrm{~d}), 68.8(\mathrm{~d})$, 68.3 (d), 67.4 (d), one oxygenated quaternary carbon at $\delta 75.9$ (s), in addition to five $s p^{2}$ methine carbons, three $s p^{2}$ quaternary carbons, seven aliphatic methylenes, four aliphatic methines and six methyls. The above NMR data showed that the compound $\mathbf{1}$ has the milbe-

Table $1{ }^{1} \mathrm{H}$ - and ${ }^{13} \mathrm{C}$ NMR data of milbemycin $\beta_{15}(1)$, secomilbemycins $E$ (2) and $F(3)$ (coupling constants in parenthesis)

\begin{tabular}{|c|c|c|c|c|c|c|}
\hline \multirow[b]{2}{*}{ Number } & \multicolumn{3}{|c|}{ Proton } & \multicolumn{3}{|c|}{ Carbon } \\
\hline & (1) & (2) & (3) & (1) & (2) & (3) \\
\hline 2 & $3.47 \mathrm{~d}(2.0)$ & & & $49.2 \mathrm{~d}$ & $123.0 \mathrm{~s}$ & $123.0 \mathrm{~s}$ \\
\hline 3 & 5.29 br s & $7.92 \mathrm{br} \mathrm{s}$ & $7.92 \mathrm{br} \mathrm{s}$ & $118.0 \mathrm{~d}$ & $130.6 \mathrm{~d}$ & $130.6 \mathrm{~d}$ \\
\hline 4 & & & & $139.2 \mathrm{~s}$ & $138.5 \mathrm{~s}$ & $138.5 \mathrm{~s}$ \\
\hline 6 & $1.90 \mathrm{~m}$ & & & & & \\
\hline 7 & & & & $75.9 \mathrm{~s}$ & $135.9 \mathrm{~s}$ & $135.9 \mathrm{~s}$ \\
\hline 8 & & & & $139.5 \mathrm{~s}$ & $124.1 \mathrm{~s}$ & $124.1 \mathrm{~s}$ \\
\hline 9 & $6.41 \mathrm{~d}(11.2)$ & $6.65 \mathrm{~d}(11.2)$ & $6.65 \mathrm{~d}(11.2)$ & $129.8 \mathrm{~d}$ & $127.6 \mathrm{~d}$ & $127.6 \mathrm{~d}$ \\
\hline 10 & $6.26 \mathrm{dd}(14.6,11.2)$ & $6.32 \mathrm{dd}(14.9,11.2)$ & $6.32 \mathrm{dd}(14.9,11.2)$ & $123.9 \mathrm{~d}$ & $122.5 \mathrm{~d}$ & $122.5 d$ \\
\hline 11 & $5.50 \mathrm{dd}(14.6,9.9)$ & $5.94 \mathrm{dd}(14.9,7.6)$ & $5.95 \mathrm{dd}(14.9,7.6)$ & $144.1 \mathrm{~d}$ & $146.6 \mathrm{~d}$ & $146.6 \mathrm{~d}$ \\
\hline 15 & $4.85 \mathrm{br} \mathrm{d}(6.8)$ & $5.22 \mathrm{t}(6.7)$ & $5.22 \mathrm{t}(6.9)$ & $120.8 d$ & $122.5 \mathrm{~d}$ & $122.5 \mathrm{~d}$ \\
\hline 16 & $2.23 \mathrm{~m}$ & $2.23 \mathrm{~m}$ & $2.23 \mathrm{~m}$ & $34.5 \mathrm{t}$ & $34.4 \mathrm{t}$ & $34.4 \mathrm{t}$ \\
\hline 17 & $3.59 \mathrm{~m}$ & $3.52 \mathrm{~m}$ & $3.53 \mathrm{~m}$ & $67.4 \mathrm{~d}$ & $68.0 \mathrm{~d}$ & $68.1 \mathrm{~d}$ \\
\hline \multirow[t]{2}{*}{18} & $1.75 \mathrm{~m}$ & $1.97 \mathrm{~m}$ & $1.97 \mathrm{~m}$ & $36.8 \mathrm{t}$ & $40.3 \mathrm{t}$ & $40.4 \mathrm{t}$ \\
\hline & $0.77 \mathrm{~m}$ & $1.13 \mathrm{t}(11.8)$ & $1.14 \mathrm{t}(11.8)$ & & & \\
\hline 19 & $5.33 \mathrm{~m}$ & $4.09 \mathrm{~m}$ & $4.10 \mathrm{~m}$ & $68.8 \mathrm{~d}$ & $64.8 \mathrm{~d}$ & $65.0 \mathrm{~d}$ \\
\hline \multirow[t]{2}{*}{20} & $1.93 \mathrm{~m}$ & $1.97 \mathrm{~m}$ & $2.00 \mathrm{~m}$ & $41.3 \mathrm{t}$ & $44.8 \mathrm{t}$ & $45.0 \mathrm{t}$ \\
\hline & 1.37 t (11.8), & $1.28 \mathrm{~m}$ & $1.28 \mathrm{~m}$ & & & \\
\hline 21 & & & & $97.4 \mathrm{~s}$ & $97.4 \mathrm{~s}$ & $97.2 \mathrm{~s}$ \\
\hline \multirow[t]{2}{*}{22} & $1.64 \mathrm{~m}$ & $1.65 \mathrm{~m}$ & $1.65 \mathrm{~m}$ & $35.7 \mathrm{t}$ & $35.8 \mathrm{t}$ & $35.7 \mathrm{t}$ \\
\hline & $1.49 \mathrm{~m}$ & $1.52 \mathrm{~m}$ & $1.52 \mathrm{~m}$ & & & \\
\hline 23 & $1.49 \mathrm{~m}$ & $1.52 \mathrm{~m}$ & $1.52 \mathrm{~m}$ & $28.0 \mathrm{t}$ & $27.8 \mathrm{t}$ & $28.0 \mathrm{t}$ \\
\hline
\end{tabular}


Table 1 (Continued)

\begin{tabular}{|c|c|c|c|c|c|c|}
\hline \multirow[b]{2}{*}{ Number } & \multicolumn{3}{|c|}{ Proton } & \multicolumn{3}{|c|}{ Carbon } \\
\hline & (1) & (2) & (3) & (1) & (2) & (3) \\
\hline \multirow[t]{2}{*}{27} & $4.23 \mathrm{~d}(12.2)$ & $5.15 \mathrm{br} \mathrm{s}$ & 5.16 br s & $57.8 \mathrm{t}$ & $66.5 \mathrm{t}$ & $66.5 \mathrm{t}$ \\
\hline & $4.18 \mathrm{~d}(12.2)$ & & & & & \\
\hline 28 & $1.03 \mathrm{~d}(6.8)$ & $1.03 \mathrm{~d}(6.7)$ & $1.03 \mathrm{~d}(6.7)$ & $21.7 \mathrm{q}$ & $19.8 q$ & $19.8 \mathrm{q}$ \\
\hline \multirow[t]{2}{*}{31} & $1.85 \mathrm{~m}$ & $1.09 \mathrm{~d}(6.4)$ & $1.62 \mathrm{~m}$ & $28.3 d$ & $19.4 \mathrm{q}$ & $25.8 \mathrm{t}$ \\
\hline & & & $1.26 \mathrm{~m}$ & & & \\
\hline 32 & $0.84 \mathrm{~d}(6.8)$ & & $0.89 \mathrm{t}(7.1)$ & $14.1 \mathrm{q}$ & & $10.2 q$ \\
\hline 33 & $1.01 \mathrm{~d}(7.0)$ & & & $20.9 q$ & & \\
\hline $7-\mathrm{OH}$ & $3.86 \mathrm{~s}$ & & & & & \\
\hline
\end{tabular}

By DEPT sequence.
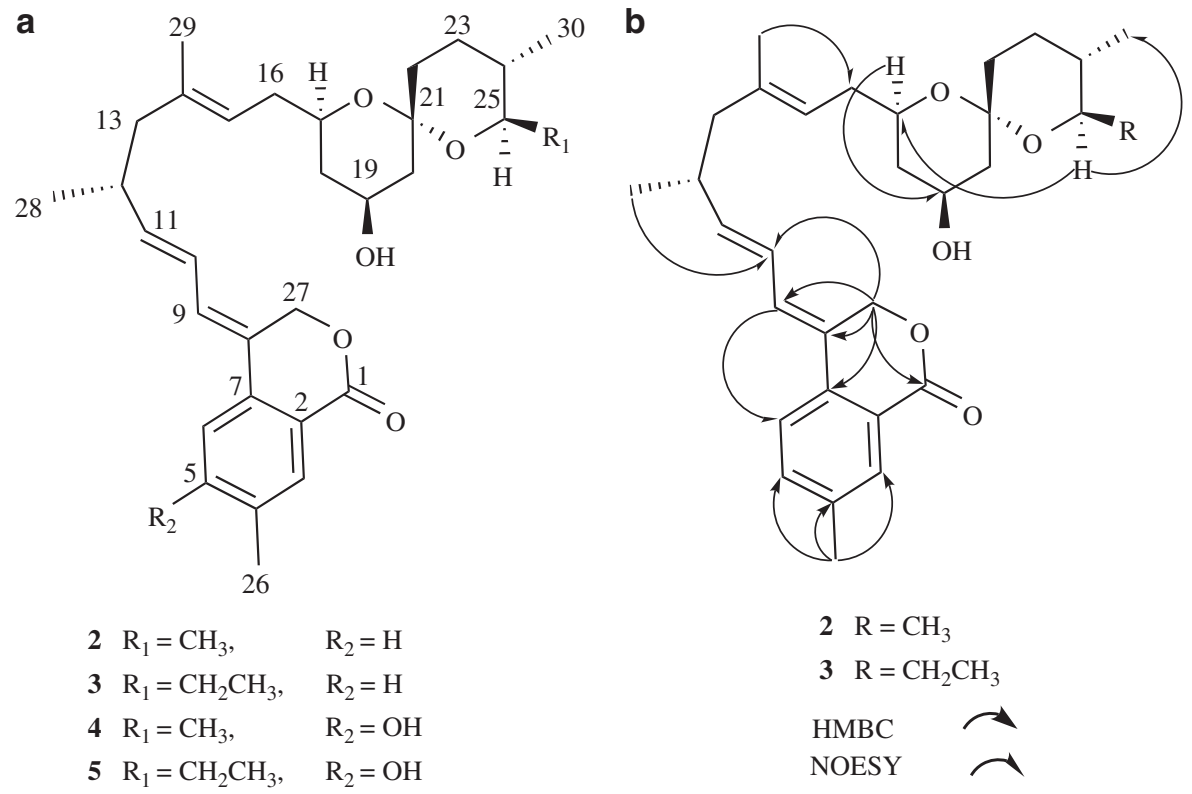

Figure 2 The structures (a) of compounds 2, 3, $\mathbf{4}$ and 5, as well as the key correlations of HMBC and NOESY (b) compounds 2 and $\mathbf{3}$.

mycin skeleton. In the ${ }^{1} \mathrm{H}-{ }^{1} \mathrm{H}$ COSY spectrum (Figure 1), the correlations from $\delta 0.84\left(\mathrm{H}_{3}-32\right), 1.01\left(\mathrm{H}_{3}-33\right)$ and $1.85(\mathrm{H}-31)$ and the HMBC crossing signals (Figure 1) between $\delta 0.84,1.01$ and $\delta 28.3$ (C-31) indicated the presence of an isopropyl moiety. Comparison of the ${ }^{1} \mathrm{H}$ and ${ }^{13} \mathrm{C}$ NMR spectral data of compound 1 with those of milbemycin $\beta_{12}{ }^{13}$ revealed that compound 1 was similar to those of milbemycin $\beta_{12}$, except for the substituents at C-8 and C-25, where the methyl at C-8 and the ethyl group at C-25 in milbemycin $\beta_{12}$ were replaced by a hydroxymethyl group and isopropyl group in compound 1, respectively. The observed $\mathrm{HMBC}$ correlations (Figure 1) from $\mathrm{H}_{3}-32\left(\delta_{\mathrm{H}} 0.84\right) / \mathrm{H}_{3}-33\left(\delta_{\mathrm{H}} 1.01\right)$ to $\mathrm{C}-25\left(\delta_{\mathrm{C}} 78.3\right)$ and from $\mathrm{H}_{2}-27$ $\left(\delta_{\mathrm{H}} 4.18,4.23\right)$ to $\mathrm{C}-7\left(\delta_{\mathrm{C}} 75.9\right), \mathrm{C}-9\left(\delta_{\mathrm{C}} 129.8\right), \mathrm{C}-8\left(\delta_{\mathrm{C}} 139.5\right)$ confirmed the structural assignment of compound 1 . Thus, the gross structure of compound $\mathbf{1}$ was established.

In compound 1, the large $J(14.6 \mathrm{~Hz})$ of $\mathrm{H}-10$ and $\mathrm{H}-11$ and the NOESY crossing peaks (Figure 1) between $\mathrm{H}_{2}-27$ and $\mathrm{H}-10, \mathrm{H}_{3}-29$ and $\mathrm{H}_{2}-16$ indicated that the three double bonds at C-8 and C-9, C-10 and C-11, C-14 and C-15 were E. The NOESY correlations of $\mathrm{H}-17$, $\mathrm{H}_{3}-30$ and $\mathrm{H}-25, \mathrm{H}-17$ and $\mathrm{H}-19, \mathrm{H}-11$ and $\mathrm{H}_{3}-28$ suggested that these protons having the same orientations as in milbemycin $\beta_{12}$.

From a biogenetic point of view, the relative stereochemistry of the chiral centers in compound 1 was assigned based on that of milbemycin $\mathrm{E}^{14}$ and milbemycin $\beta_{12}$. The assumption was supported by the similar optical rotation values of $\mathbf{1}$ and milbemycin $\mathrm{E}$ $\left([\alpha]_{\mathrm{D}}^{27}+157\right.$ (c 0.25 , acetone)).

Compound 2 (Figure 2a) was obtained as colorless oil with UV $(\mathrm{EtOH}) \lambda_{\max }(\mathrm{nm})(\log \varepsilon): 288(4.08)$ and $[\alpha]_{\mathrm{D}}^{25}+29.6(\mathrm{c} 0.27, \mathrm{EtOH})$. Its molecular formula was established to be $\mathrm{C}_{31} \mathrm{H}_{42} \mathrm{O}_{5}$ as deduced from the HRESI-MS $m / z 517.3027[\mathrm{M}+\mathrm{Na}]^{+}$(calcd for $\mathrm{C}_{31} \mathrm{H}_{42} \mathrm{O}_{5} \mathrm{Na}$ 517.3006) and ${ }^{13} \mathrm{C}$ NMR data (Table 1). The IR spectrum of compound 2 showed absorption bands assignable to the hydroxyl group $\left(3454 \mathrm{~cm}^{-1}\right)$ and an ester carbonyl $\left(1724 \mathrm{~cm}^{-1}\right)$. The ${ }^{1} \mathrm{H}$ NMR $\left(400 \mathrm{MHz}, \mathrm{CDCl}_{3}\right)$ data (Table 1) of compound 2 displayed one trans double bond at $\delta 5.90(\mathrm{dd}, J=14.9,7.6 \mathrm{~Hz})$ and $\delta 6.32(\mathrm{dd}, J=14.9$, 
$11.2 \mathrm{~Hz}$ ), one aromatic methyl at $\delta 2.39$ (s), one vinylic methyl at $\delta 1.62$ (br s), and three aliphatic methyls at $\delta 0.82(\mathrm{~d}, J=6.5 \mathrm{~Hz})$, $1.03(\mathrm{~d}, J=6.7 \mathrm{~Hz})$ and $1.09(\mathrm{~d}, J=6.4 \mathrm{~Hz})$. The signals at $\delta 7.38(1 \mathrm{H}$, dd, $J=8.4,1.6 \mathrm{~Hz}), 7.47(1 \mathrm{H}, \mathrm{d}, J=8.4 \mathrm{~Hz})$ and $7.92(1 \mathrm{H}, \mathrm{br} \mathrm{s})$ in the ${ }^{1} \mathrm{H}$ NMR spectrum of compound 2 showed the presence of a 1, 2, 4-trisubstituted benzene ring moiety. Its ${ }^{13} \mathrm{C} \mathrm{NMR}$ and DEPT data (Table 1) revealed an ester carbonyl at $\delta 165.1$ (s), a ketal at $\delta 97.4$ (s), three oxygenated methines, one oxygenated methylene, in addition to $12 s p^{2}$ carbons, 6 aliphatic methylene, 2 aliphatic methines and 5 methyls. Comparison of the ${ }^{1} \mathrm{H}$ and ${ }^{13} \mathrm{C}$ NMR spectral data of compound 2 with those of seco-milbemycin C (compound 4, Figure $2 \mathrm{a})^{3}$ revealed that compound 2 was almost identical to those of seco-milbemycin $\mathrm{C}$, except for the substituent at C-5, where the hydroxy in seco-milbemycin $\mathrm{C}$ was replaced by a hydrogen atom in compound 2. The observed HMBC correlations (Figure 2b) from $\mathrm{H}-27\left(\delta\right.$ 5.15) to $\mathrm{C}-1\left(\delta\right.$ 165.1) and from $\mathrm{H}_{3}-26(\delta$ 2.39) to $\mathrm{C}-3$ $(\delta$ 130.6), and from C-4 $(\delta 138.5)$ and C-5 $(\delta 134.9)$ further confirmed the structural assignment of compound 2 . Thus, the gross structure of compound 2 was established.

In compound 2, the NOESY correlations (Figure 2b) between $\mathrm{H}-27$ and $\mathrm{H}-10$ and between $\mathrm{H}-6$ and $\mathrm{H}-9$ indicated the $\Delta^{8}$ olefin was transdouble bond as in seco-milbemycin $C$. The $E$ configuration of the $\Delta^{10}$ olefin of compound 2 was assigned by the large $J(14.9 \mathrm{~Hz})$ between $\mathrm{H}-10$ and $\mathrm{H}-11$. The NOESY correlation signal between $\mathrm{H}-29$ and $\mathrm{H}-16$ revealed that the double bond of C-14 and C-15 was E. Furthermore, the NOESY correlations (Figure 2a) of $\mathrm{H}-17, \mathrm{H}_{3}-30$ and $\mathrm{H}-25, \mathrm{H}-17$ and $\mathrm{H}-19, \mathrm{H}-10$ and $\mathrm{H}_{3}-28$ showed the orientation of these protons. Thus, the structure of compound 2 was established. Biogenetically, the relative stereochemistry of the chiral centers in compound 2 was assigned based on that of seco-milbemycin C. The assumption was supported by the similarity of optical rotation values between compound 2 and secomilbemycin $\mathrm{C}\left([\alpha]_{\mathrm{D}}^{20}+25\right.$ (c $0.20, \mathrm{EtOH})$ ).

Compound 3 (Figure 2a) was also isolated as colorless oil with $[\alpha]_{\mathrm{D}}^{25}+32.9$ (c 0.28, EtOH) and UV (EtOH) $\lambda_{\max }(\mathrm{nm})(\log \varepsilon): 287$ (4.11). The HRESI-MS gave the molecular formula $\mathrm{C}_{32} \mathrm{H}_{44} \mathrm{O}_{5}$ (found: 531.3133 $[\mathrm{M}+\mathrm{Na}]^{+}$, calcd: 531.3149). Its ${ }^{1} \mathrm{H}$ and ${ }^{13} \mathrm{C} \mathrm{NMR}$ data (Table 1) were very similar to those of compound 2. Comparison of the ${ }^{1} \mathrm{H}$ and ${ }^{13} \mathrm{C}$ NMR data of compound 3 with those of compound 2 , suggested that compound $\mathbf{3}$ was structurally related to compound $\mathbf{2}$. The difference between compounds 3 and 2 could be explained by the replacement of a methyl substituent in C- 25 in compound 2 by an ethyl group in compound $\mathbf{3}$. The stereostructure of compound $\mathbf{3}$ was assigned as that of compound 2 by the analysis of the NMR data and NOESY correlation signals (Figure 2b). Further comparison of the NMR data with those of seco-milbemycin A (compound 5, Figure 2a) ${ }^{2}$ confirmed the structure assignment of compound 3 .

The acaricidal activity against adult two-spotted spider mites (Tetranychus urticae Koch) and mite eggs as well as nematocidal activity against Caenorhabditis elegans of compounds 1, 2 and $\mathbf{3}$ were evaluated according to the methods described previously. ${ }^{1,4,5}$ Although these compounds showed potent acaricidal and nematocidal activities (data not shown), the bioactivities were weaker than those of the commercial acaricide and nematocide milbemycins $\mathrm{A}_{3} /$ $\mathrm{A}_{4}$. However, the discovery of compounds 1, 2 and 3 in the mutant S. bingchenggensis X-4 may shed new insight into the biosynthesis of milbemycin.

\section{ACKNOWLEDGEMENTS}

This research work was financially supported by the National Natural Science Foundation of China (30971937), the Program for New Century Excellent Talents in University (NCET-08-0668, 1154-NCET-002), the Outstanding Youth Foundation of Heilongiiang Province (JC200706), the National Key Project for Basic Research (2010CB126102) and the Program for New Teachers in University (20092325120007).

1 Xiang, W. S., Wang, J. D., Wang, X. J. \& Zhang, J. Two new-class milbemycins from Streptomyces bingchenggensis fermentation, isolation, structure elucidation and biological properties. J. Antibiot. 60, 351-356 (2007).

2 Xiang, W. S., Wang, J. D., Fan, H. M., Wang, X. J. \& Zhang, J. New seco-milbemycins from Streptomyces bingchenggensis: fermentation, isolation and structure elucidation. J. Antibiot. 61, 27-32 (2008).

3 Wang, X. J., Wang, J. D., Xiang, W. S. \& Zhang, J. Three new milbemycin derivatives from Streptomyces bingchenggensis. J. Asian. Nat. Prod. Res. 11, 597-603 (2009).

4 Xiang, W. S., Wang, J. D., Wang, X. J., \& Zhang, J. A novel macrolide compound from Streptomyces bingchenggensis: fermentation, isolation, structure elucidation and biological properties. J. Antibiot. 62, 229-231 (2009).

5 Xiang, W. S., Wang, J. D., Wang, X. J. \& Zhang, J. Bingchamides A and B, two novel cyclicpentapeptides from the Streptomyces bingchenggensis: fermentation, isolation, structure elucidation and biological properties. J. Antibiot. 62, 501-505 (2009).

6 Shoop, W. L., Mrozik, H. \& Fisher, M. H. Structure and activity of avermectins and milbemycins in animal health. Vet. Parasitol. 59, 139-156 (1995).

7 Sasaki, Y., Kitagawa, H. \& Ishihara, K. Clinical application of milbemycin D as a prophylactic agent against Dirofilaria immitis infection in dogs: clinical findings in dogs with shock-like reaction. Nippon Juigaku Zasshi. 48, 1207-1214 (1986).

8 Takiguchi, Y. et al. Milbemycins, a new family of macrolide antibiotics: fermentation, isolation and physico-chemical properties. J. Antibiot. 33, 1120-1127 (1980).

9 Burg, R. W. et al. Avermectins, new family of potent anthelmintic agents: producing organism and fermentation. Antimicrob. Agents Chemother. 15, 361-367 (1979).

10 Pitterna, T. et al. New ventures in the chemistry of avermectins. Bioorg. Med. Chem. 17, 4085-4095 (2009).

11 Berendsen, B. J., Mulder, P. P. \& van Rhijn, H. J. The derivatisation of avermectins and milbemycins in milk: new insights and improvement of the procedure. Anal. Chim. Acta. 585, 126-133 (2007).

12 Wang, X. J., Wang, X. C. \& Xiang, W. S. Improvement of milbemycin-producing Streptomyces bingchenggensis by rational screening of ultraviolet and chemically induced mutants. World J. Microbiol. Biotechnol. 25, 1051-1056 (2009).

13 Nonaka, K. et al. New milbemycins from Streptomyces hygroscopicus subsp. aureolacrimosus: fermantation, isolation and structure elucidation. J. Antibiot. 53, 694-704 (2000).

14 Mishima, H., Ide, J., Muramatsu, S. \& Ono, M. Milbemycins, a new family of macrolide antibiotics. Structure determination of milbemycins D, E, F, G, H, J and K. J. Antibiot. 36, 980-990 (1983). 